\title{
Upaya Melatihkan Kemampuan Pemecahan Masalah Melalui Pembelajaran Fisika dengan Model Cooperative Problem Solving (CPS)
}

\author{
Dwi Ratnaningdyah ${ }^{1)}$ \\ 1) Universitas PGRI Palembang, Palembang, Indonesia \\ E-mail:dwi.dyalovai@gmail.com
}

\begin{abstract}
Abstrak. Makalah ini merupakan hasil dari kajian literatur tentang model pembelajaran Cooperative Problem Solving (CPS) yang dapat meningkatkan kemampuan pemecahan masalah siswa pada mata pelajaran fisika. Kemampuan pemecahan masalah merupakan salah satu karakter yang diharapkan dimiliki oleh siswa dalam menghadapi masalah di kehidupan bermasyarakat. Dengan diberlakukannya Masyarakat Ekonomi ASEAN (MEA) di Indonesia, menjadi peluang dan sekaligus tantangan bagi kita. MEA yang menganut sistem bebas melakukan perdagangan di negara-negara ASEAN ini menuntut kita untuk lebih kreatif dan inovatif dalam memecahkan masalah yang dihadapi. Pendidikan menjadi pilar utama untuk menghasilkan insan yang dapat bertahan dengan segala hantaman permasalahan hidup. Oleh karenanya, diperlukan suatu upaya untuk melatihkan kemampuan pemecahan masalah sejak dini yaitu sejak berada di bangku sekolah. Salah satu upaya yang dapat dilakukan adalah dengan melatihkan kemampuan masalah itu melalui strategi pembelajaran CPS. Terdapat lima tahap strategi problem solving menurut Heller \& Heller (2010) yaitu memahami permasalahan, mengubah permasalahan sehari-hari ke konsep fisika, merencanakan solusi, menggunakan solusi, dan mengevaluasi solusi. Dengan kondisi sekolah di Indonesia yang memiliki kelas dengan rombongan belajar yang besar, maka dapat menggunakan teknik pembelajaran berkelompok (cooperative learning). Telah banyak penelitian yang mengungkapkan bahwa pembelajaran kooperatif dapat memotivasi siswa dalam belajar. Menurut Johnson \& Smith dalam Heller (2010), di dalam pembelajaran kooperatif terdapat unsur-unsur pengembangan pribadi yaitu keterkaitan yang positif (Possitive interdepence), interaksi antarmuka (Face-to-face promotive interaction), tanggung jawab individu (Individual Accountability/Personal Responsibility), dan keterampilan berkolaborasi (Collaborative Skill).
\end{abstract}

Kata Kunci: cooperative problem solving, kemampuan pemecahan masalah

\section{Pendahuluan}

Fisika merupakan bidang pelajaran yang menyangkut fenomena-fenomena alam, dan siswa dituntut untuk memahami konsep-konsep yang ada pada fenomenafenomena alam tersebut. Dengan kata lain, siswa dilibatkan dalam proses membangun suatu model yang dapat membantu mereka untuk memahami hubungan dan perbedaan antara konsep-konsep fisika dalam fenomena di alam. Agar siswa dapat membangun konsep suatu ilmu pengetahuan fisika, salah satu kegiatan yang harus dilalui oleh siswa adalah belajar di kelas. Oleh karena itu, kegiatan belajar mengajar di sekolah merupakan hal yang sangat penting untuk melatihkan suatu keterampilan ataupun konsep ilmu pengetahuan.

Kompetensi Inti siswa SMP dalam Kurikulum 2013 menyebutkan bahwa Ilmu Pengetahuan Alam dan Ilmu Pengetahuan Sosial dikembangkan sebagai mata pelajaran integrative science dan integrative social studies, bukan sebagai pendidikan disiplin ilmu. Keduanya sebagai pendidikan berorientasi aplikatif, pengembangan kemampuan berpikir, kemampuan belajar, rasa ingin tahu, dan pengembangan sikap peduli dan bertanggung jawab terhadap lingkungan sosial dan alam. Terdapat beberapa jenis kemampuan berpikir antara lain, kemampuan berpikir kritis, kreatif, berpikir rasional dan lain-lain. Dengan demikian, tujuan pembelajaran di sekolah adalah melatih siswa untuk mengembangkan kemampuan berpikirnya. Salah satu kemampuan berpikir adalah kemampuan memecahkan masalah. Kemampuan memecahkan masalah merupakan salah satu jenis dari berpikir tingkat tinggi.

Dalam kaitannya dengan berlakunya Masyarakat Ekonomi ASEAN (MEA) di Indonesia, maka kemampuan memecahkan masalah merupakan kemampuan yang harus dimiliki oleh setiap orang pada umumnya, dan usahawan pada khususnya.

Dari uraian di atas, dapat diartikan bahwa salah faktor terpenting dalam pembelajaran adalah kegiatan di sekolah sebagaimana yang telah ditetapkan oleh pemerintah. Belajar merupakan kegiatan yang paling pokok dalam keseluruhan proses di sekolah. Ini berarti keberhasilan dalam mencapai tujuan pendidikan sangat dipengaruhi oleh proses belajar yang 


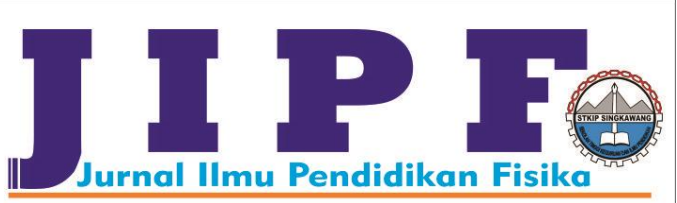

dialami siswa sebagai peserta didik. Dalam proses pembelajaran terdapat unsur-unsur yang menjadi pondasi kegiatan belajar mengajar yaitu strategi belajar. Strategi belajar mencakup model pembelajaran, metode pembelajaran, serta hal lain yang mendukung proses pembelajaran itu sendiri.

Menurut Muslimin dkk (Iman, 2010), semua model pembelajaran ditandai dengan adanya struktur tugas, struktur tujuan, dan struktur penghargaan. Model pembelajaran yang telah ditemukan hingga saat ini sudah sangat beragam dan berkembang. Misalnya, model pembelajaran kooperatif, model pembelajaran inkuiri, model pembelajaran kontekstual, model pembelajaran konstruktivisme, dan lain-lain.

\section{METODE}

Adapun metode yang digunakan dalam penelitian yang telah dilakukan yakni studi literatur. Literatur-literatur yang digunakan dalam penelitian yang telah dilakukan adalah buku dan jurnal-jurnal ilmiah.

\section{HASIL DAN PEMBAHASAN}

Masalah adalah sesuatu yang harus dipecahkan (KBBI). Pemecahan masalah merupakan kemampuan berpikir yang dibutuhkan ketika tujuan tidak tercapai secara otomatis dan siswa harus menggunakan satu atau lebih proses berpikir tingkat tinggi untuk mencapainya [1].

Kemampuan pemecahan masalah yang dimaksud dalam penelitian ini adalah kemampuan siswa menggunakan pengetahuan-pengetahuan dan konsep-konsep cahaya yang dipelajarinya untuk menemukan solusi atas masalah-masalah "kaya konteks" (context-rich problems) yang menghitung sejumlah kuantitas mengenai objek atau peristiwa nyata. Kemampuan pemecahan masalah yang digunakan dalam penelitian ini mengacu pada kemampuan pemecahan masalah menurut Heller \& Heller berdasarkan strategi problem solving, yaitu kemampuan memvisualisasikan masalah, menguraikan secara konsep fisika, merencanakan solusi, melaksanakan perencanaan, dan melakukan pengecekan dan evaluasi. Kriteria penilaian kemampuan pemecahan masalah berdasarkan pada tingkat penyelesaian yang sesuai dengan konsep yang telah dipelajari dalam meyelesaikan masalah. Kemampuan pemecahan masalah diukur dengan menggunakan tes berbentuk esai yang berisi masalah-masalah "kaya konsteks".

Adapun karakteristik masalah-masalah "kaya konteks" antara lain:

1. Permasalahan harus cukup menantang

2. Masalah harus terstruktur sehingga kelompok dapat membuat keputusan tentang bagaimana proses solusinya.

3. Masalah harus relevan dengan kehidupan para siswa

4. Masalah tidak dapat bergantung hanya pada trik pengetahuan atau matematis siswa.

Model pembelajaran CPS diadopsi dan diadaptasi dari strategi CPS yang fase-fase kegiatannya dihubungkan dengan kegiatan siswa di sekolah. Strategi Pembelajaran CPS dikembangkan oleh Heller \& Heller, sepasang fisikawan dari Universitas Minnesota, Amerika Serikat. Model CPS merupakan perpaduan antara strategi Problem Solving dan Cooperative Learning. CPS tercetus karena adanya pembelajaran dengan kelas besar, yang memungkinkan siswa berkelompok untuk memecahkan permasalahan yang diberikan. CPS dikembangkan di Universitas Minnesota pada materi pendahuluan fisika di kelas besar [2].

CPS yang dikembangkan oleh Heller \& Heller merupakan pengembangan dari strategi problem solving oleh Polya, seorang matematikawan yang mengemukakan tahap-tahapnya sebagai berikut;

Menurut Polya [2]

1. Understand the Problem (memahami masalah)

2. Devise a Plan (merencanakan solusi)

3. Carry Out the Plan (menggunakan solusi)

4. Look Back (memeriksa kembali solusi)

Sedangkan menurut Heller \& Heller (2010), terdapat 5 langkah dalam strategi problem solving, yaitu:

1. Recognize the problem (memahami masalah)

2. Describe the problem in terms of the field (menggambarkan masalah dalam istilah fisika)

3. Plan a solution (merencanakan solusi)

4. Execute the plan (menggunakan solusi)

5. Evaluate the solution (mengevaluasi solusi)

Pembelajaran kooperatif pada CPS tidak hanya agar siswa dapat berdiskusi secara kelompok, tapi juga agar unsur-unsur dalam pembelajaran kooperatif dapat tercapai. Unsur-unsur Cooperative Learning adalah [2] :

1) Keterkaitan yang positif (Possitive interdepence)

Keterkaitan yang positif antar anggota dalam kelompok dapat digambarkan bahwa setiap anggota harus berkontribusi terhadap kemajuan kelompok atau kelompok tidak akan sukses jika tidak didukung oleh semua anggota.

2) Interaksi antarmuka (Face-to-face promotive interaction) Kegiatan diskusi antar anggota kelompok dapat membantu dalam menghubungkan pengetahuan awal dan pengetahuan baru, dapat melatihkan strategi pemecahan masalah, dan dapat menjadi pengajaran sebaya (peerteaching).

3) Tanggung jawab individu (Individual Accountability/Personal Responsibility)

Melatihkan sikap tanggung jawab setiap anggota kelompok dalam keberhasilan kelompok.

4) Keterampilan berkolaborasi (Collaborative Skill) Siswa dapat melatihkan kemampuan kepemimpinan, pembuat keputusan, membangun kepercayaan, komampuan komunikasi, dan keterampilan mengatasi konflik antar anggota kelompok.

Tahapan strategi CPS menurut Heller \& Heller (2010) adalah:

Tahap 1 : Recognize the problem. (Apa masalahnya?)

Masalah yang diberikan pada proses pembelajaran adalah contoh kejadian nyata sehari-hari. Siswa diberikan suatu permasalahan dengan subjeknya adalah siswa itu sendiri (siswa dihadapkan pada masalah). Permasalahan disajikan 


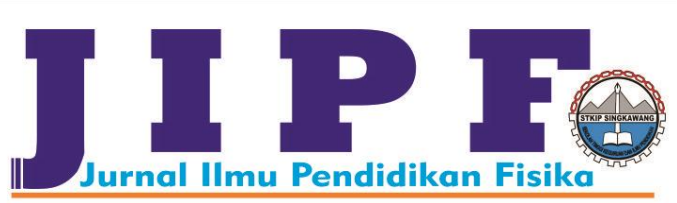

dalam bentuk cerita tanpa gambar maupun diagram. Dengan keikutsertaan siswa pada masalah tersebut, diharapkan dapat memotivasi siswa untuk memecahkannya.

Tahap 2 : Describe the problem in terms of the field. (Apa yang harus dilakukan dengan konsep pelajaran?)

Setelah siswa diberikan suatu masalah nyata, kemudian siswa diarahkan untuk menafsirkan dan menggambarkan masalah tersebut dalam bentuk rancangan konsep yang akan dipelajari. Penggambaran dapat berupa diagram ataupun persamaan matematis.

Tahap 3 : Plan a solution. (Bagaimana cara memecahkan masalah?)

Siswa diarahkan untuk merancang solusi dari masalah yang telah digambarkan sebelumnya. Setiap kelompok bisa saja memiliki solusi yang berbeda. Oleh karena itu, guru harus memberikan umpan balik secara langsung pada tiap kelompok.

Tahap 4 : Execute the plan. (Gunakan solusi untuk menyelesaikan masalah!)

Siswa menggunakan solusi yang telah dirancang untuk menyelesaikan permasalahan yang dihadapi.

Tahap 5 : Evaluate the solution. (Apakah solusi sudah benar?) Langkah terakhir setelah menggunakan solusi yang dirancang adalah mengevaluasi kembali apakah solusi tersebut sudah tepat. Adakah solusi lain? Apakah jawaban telah sesuai dengan apa yang ditanyakan? Bagaimana satuannya?

Penelitian tentang strategi problem solving dan model pembelajaran Novick telah banyak dilakukan di antaranya yaitu oleh Selcuk (2008) bahwa strategi problem solving lebih efektif dalam meningkatkan hasil belajar ranah kognitif, kinerja belajar, dan frekuensi aktivitas memecahkan masalah siswa [3]. Gök (2010) juga meneliti bahwa strategi pemecahan masalah lebih efektif dalam pembelajaran kooperatif daripada dalam pembelajaran konvensional [4]. Ditemukan pula bahwa telah terjadi peningkatan pada cara siswa memecahkan masalah fisika. Persepsi siswa bahwa fisika terlalu sulit tampak telah memudar [5].

\section{KESIMPULAN}

Penerapan model pembelajaran Cooperative Problem Solving (CPS) diharapkan dapat menjadi salah satu upaya dalam melatihkan kemampuan memecahkan masalah pada siswa. Dengan melatihkan kemampuan pemecahan masalah sejak dini, diharapkan ketika terjun ke masyarakat siswa dapat mengatasi masalah yang dihadapinya di masyarakat. Dengan demikian, diharapkan siswa yang akan menghadapi MEA dapat bersaing dengan negara-negara lain.

Dari pemaparan penulis tentang upaya melatihkan kemampuan memecahkan masalah melalui model pembelajaran Cooperative Problem Solving (CPS), penulis dapat memberikan rekomendasi untuk menerapkan model ini di kelas. Penerapan pembelajaran ini dapat menjadi alternatif solusi untuk mengatasi kemampuan pemecahan masalah siswa yang masih rendah. Dengan demikian, penerapan model
Jurnal Ilmu Pendidikan Fisika

Volume 2 Number 1 month March 2017. Page 1-3 p-ISSN: 2477-5959 e-ISSN: 2477-845I

pembelajaran CPS dapat menjadi salah satu upaya untuk mempersiapkan rakyat Indonesia dalam menghadapi Masyarakat Ekonomi ASEAN (MEA).

\section{UCAPAN TERIMAKASIH}

Ucapan terima kasih diberikan kepada STKIP Singkawang yang telah memfasilitasi penulis sehingga tulisan ini dapat dipublikasikan dalam berkala ilmiah STKIP Singkawang.

\section{DAFTAR PUSTAKA}

[1] Nitko \& Brookhart, Educational Assessment of Students (Fifth Edition), New Jersey: Pearson Education, Inc, 2007.

[2] Heller, K \& P. Heller. (2010). Cooperative Problem Solving in Physics A User's Manual. [Online]. Tersedia: http://www.aapt.org/Conferences/newfaculty/upload/Co op-Problem-Solving-Guide.pdf

[3] Selçuk, G. S. \& M. Erol. (2008). The Effects of Problem Solving Instruction on Physics Achievement, Problem Solving Performance and Strategy Use. [Online]. Tersedia:

http://journal.lapen.org.mx/sep08/LAJPE_191_Selcuk_F .pdf

[4] Gök, T. (2010). 'The Effects of Problem Solving Strategies on Students' Achievement, Attitude and Motivation. Latin American Journal Physics Education Vol. 4 No. $1 . \quad$ [Online]. Tersedia: http://dialnet.unirioja.es/descarga/articulo/3694877.pdf

[5] Taale, Kodjo D. (2011). Improving Physics Problem Solving Skills of Students of Somanya Senior High Secondary Technical School in the Yilo Krobo District of Eastern Region of Ghana. Journal of Education and Practice Vol 2, No 6, 2011. [Online]. Tersedia: http://www.iiste.org/Journals/index.php/JEP/article/dow nload/522/408 